\title{
Critical Autoethnography in Pursuit of Educational Equity: Introduction to the IJME Special Issue
}

\author{
Sherry Marx \\ Utah State University \\ U. S. A. \\ Julie L. Pennington \\ University of Nevada-Reno \\ U. S. A. \\ Heewon Chang \\ Eastern University \\ U. S. A.
}

\begin{abstract}
In this introduction to the special issue of IJME, we highlight critical autoethnography's potential for connecting the deeply personal experiences of race, gender, culture, language, sexuality, and other aspects of marginalization and privilege to the broader context of education in society. We discuss critical autoethnography as an interdisciplinary, blurred genre that transforms to fit the academic backgrounds, interests, and critical orientations of its authors. All contributors to this special issue situate their take on the genre in relevant literature and provide sociocultural critique in explicit and implicit ways.
\end{abstract}

KEYWORDS: autoethnography, critical autoethnography, qualitative methodology, educational equity, social identities

Autoethnography and Critical Autoethnography

Focus of this Special Issue in Education

Overview of the Included Articles

Conclusion

References

Author Contact

Autoethnography is a qualitative social science research methodology. In this special issue of the International Journal of Multicultural Education (IJME), we present articles that have engaged this research method as an investigative tool to explore the topics of educational equity and educational inequity from a critical perspective. Before we introduce each article with more details, we present a brief discussion of this research methodology and argue that critical autoethnography is a fitting research method that allows autoethnography researchers to use their personal experiences and sympathetic eyes to analyze and critique injustice pertaining to educational contexts. 


\section{Autoethnography and Critical Autoethnography}

Autoethnography is a qualitative method of inquiry that is becoming increasingly popular in the social sciences. This interdisciplinary approach to research centers the self as a site of inquiry. Its purpose is to translate the personal into the social science research realm with unique first-person representations that are accessible to readers both within and outside various communities in the global context. Autoethnography is recognized as an example of interdisciplinary, blurred genre that relies and builds on such qualitative traditions as ethnography, narrative, testimonio, phenomenology, and critical identity theories (e.g., Adams, Jones, \& Ellis, 2014; Chang, Ngunjiri, \& Hernandez, 2013; Jones, Adams, \& Ellis, 2015; Hughes, Pennington, \& Makris, 2012; Hughes \& Pennington, 2017; Reed-Danahay, 1997). The stories shared by autoethnographers are meant to resonate with others through their personal, emotional nature. A variety of methodological approaches, ranging from descriptive and evocative to analytic and critical, have guided solo and collaborative autoethnographies in various disciplines (e.g., Anderson, 2006; Bochner \& Ellis, 2016; Chang, 2008).

Historically, autoethnography has sought to reposition and resituate unheard voices in ways that reveal lived experiences in sociocultural contexts. It has provided narrow, but solid, pathways for stories of the socially marginalized to enter the discourse of academics. Thus, it easily lends itself to critical perspectives addressing how power and privilege play out in socio-personal lives and how these entities are reproduced as well as resisted. Deeply personal accounts of race, gender, culture, language, and other aspects of identity can powerfully illustrate how people live with and through privilege and marginalization each day. Although autoethnography can naturally embrace the critiques of societal injustice and positionality of identities, not all autoethnographers have explicitly and intentionally identified their autoethnographies as "critical autoethnography" as Boylorn and Orbe (2014) and Madison (2011) have done. To be inclusive in our presentation of critical autoethnography, we have selected a wide range of autoethnographies that embrace critical perspectives both explicitly and implicitly.

\section{Focus of this Special Issue in Education}

While autoethnography has rapidly grown in social sciences in recent years (Bochner \& Ellis, 2016), it has yet to have a strong impact in the field of education. Critical autoethnography, especially, is a relatively new form of the genre that, as yet, has had limited influence. Education, in its many forms, is an institution that mirrors the society around it, including its patterns of privilege and marginalization. Personal stories of living through and being a part of these patterns highlight for readers the ways we are all affected by and affecting institutionalized power and privilege.

The blurred genre nature of autoethnography allows it to metamorphose into various forms to suit the needs of its authors. It can be highly emotional and evocative (e.g., Ellis, 2004; Bochner 1997), analytical (Anderson, 2006), poetic (e.g., Richardson, 
1992), performative (e.g., Hamera, 2011; Jones, Adams, \& Ellis, 2016; Spry, 2016), and more. The possibilities are truly endless. This creative, flexible nature of autoethnography may be its most attractive quality; scholars who revere personal and creative writing often find it resonating, no matter their academic field. However, these very same qualities can make autoethnography intimidating to those new to the method. Its boundaries, foundations, formatting, and purpose can seem nebulous and untrustworthy.

The purpose of this special edition is to highlight the power critical autoethnography can have for illuminating privilege, power, and marginalization in educational contexts including the areas of teaching, learning, and policy. It highlights formal and informal settings, from pre-school through graduate studies, as well as careers in higher education. The selected articles critique issues in the context of the United States, Australia, Hungary, South Africa, and France. Perspectives in this special issue include those of students, faculty, and parents. All authors purposefully make their own understanding of autoethnography clear for readers. They situate their stories in methodological literature so readers can understand what fields and methods are influencing their work. All authors share analysis, connecting their stories to relevant literature so readers can understand how the personal stories relate to the larger sociocultural context. Because this issue focuses on critical autoethnography, all authors provide social critique. This collection of work illustrates what critical autoethnography can look like in the field of education. It does not define critical autoethnography; rather, it offers possibilities.

\section{Overview of the Included Articles}

In this special issue, 18 authors present nine articles: some are solo autoethnographies while others are collaborative in nature. Some are examples of autoethnogrpahy as a product whereas others are conceptual and methodological articles about autoethnography.

Rachel Salas presents critical analyses of education policy's impact on English language learners in the context of one state in the United States. Her analyses are given through two autoethnographic perspectives: one as an English language learner growing up in the United States and the other as an education scholar working on an educational policy task force.

Sherry Marx shares an autoethnographic tale of her own family's experiences with race, class, and language privilege as her children moved into and out of US and Hungarian public schools. She critically examines the advantages Whiteness, economic status, and English-language fluency gave her children in some educational contexts, as well as the disadvantages multilingualism cost them in others.

Craig Wood critically interrogates his own experience as a White teacher working with First People students in Australia. His analysis of his teaching through an event with one of his students, Sal, demonstrates the use of autoethnography as a means of reflective self-critique. 
Stephen Quaye shares autoethnographic mystory and poetry to illustrate his experiences being a Black male academic in predominantly White higher education. He critiques the White norms and racism that impact the United States presently and historically, arguing for the need to acknowledge and express anger in order to heal and survive.

Tony Adams, a seasoned scholar of autoethnography, offers guidance for those taking a critical perspective by emphasizing the power of forgiveness. Through his own autoethnographic stories, he demonstrates the healing and resilience that can come from forgiving those who inadvertently or purposefully marginalize us and forgiving ourselves when we inadvertently or purposefully do the same to others.

Aeriel Ashlee, Bianca Zamora, and Shamika Karikari share a collaborative autoethnography that critiques the racism and sexism they experience as graduate students of color in a predominantly White university. Within a framework of intersectionality, they present their journeys to "wokeness," that is, critical consciousness of both oppression and resilience.

Cynthia Helen Brock, Adeline Borti, Tia Frahm, Lori Howe, Dilnoza Khasilova, and Karen Ventura-Kalen present a collaborative autoethnography of critical narratives that illustrate how their individual experiences in academia relate to notions of equity. Through individual analysis followed by collective analysis, they illustrate how educators can use their personal understandings to inform their teaching.

Kathleen Pithouse-Morgan, Inbanathan Naicker, and Daisy Pillay present a collaborative autoethnography from South Africa where they are all higher education faculty. Together, they dialogue with the critical autoethnographic work of other South African scholars, analyzing that work through collectively composed poetry.

Deborah Reed-Danahay, a long-time scholar in the traditions of ethnography and autoethnography, highlights the role of theory as she uses Bourdieu's concept of "selfanalysis" to critically examine dualism in the insider and outsider views of research. In her analysis of autoethnography she turns to her own work, as well as to the genre and role of autoethnography in education as it relates to her own teaching.

\section{Conclusion}

We hope the critical autoethnographies presented in this special issue inspire more scholars to take up this methodology to critically examine their own experiences in education. While educational research from all traditions informs practice, policy, and instruction, autoethnography with its focus on lived experience, identity, and perspective has the potential to impact educators deeply as they seek understanding and justice for all students. The voices of educators and learners engaged in critical autoethnographic work call attention to the individual and collective experiences encased within larger educational systems and sociohistorical contexts. These voices have much potential to powerfully impact our pursuits of educational equity. 


\section{References}

Adams, T. E., Jones, S. H., \& Ellis, C. (2014). Autoethnography. Oxford, UK: Oxford University Press.

Anderson, L. (2006). Analytic autoethnography. Journal of Contemporary Ethnography, 35(4), 373-395.

Bochner, A. (1997). It's about time: Narrative and the divided self. Qualitative Inquiry, 3, 418-438.

Bochner, A., \& Ellis, C. (2016). The ICQI and the rise of autoethnography: Solidarity through community. International Review of Qualitative Research, 9(2), 208-217.

Boylorn, R. M., \& Orbe, M. P. (2014). Critical autoethnography: Intersecting cultural identities in everyday life. Walnut Creek, CA: Left Coast Press.

Chang, H. (2008). Autoethnography as method. Walnut Creek, CA: Left Coast Press.

Chang, H., Nqunjiri, F. W., \& Hernandez, K. C. (2012). Collaborative Autoethnography. Walnut Creek, CA: Left Coast Press.

Ellis, C. (2004). The ethnographic I: A methodological novel about autoethnography. Walnut Creek, CA: Alta Mira Press.

Hamera, J. (2011). Performative ethnography. In N. K. Denzin \& Y. S. Lincoln (Eds.), Sage handbook of qualitative inquiry (4th ed., pp. 317-330). Thousand Oaks, CA: Sage.

Hughes, S., Pennington, J., \& Makris, S. (2012). Translating autoethnography across the AERA standards: Toward understanding autoethnographic scholarship as empirical research. Educational Researcher, 41(6), 209-219.

Hughes, S. A., \& Pennington, J. L. (2017). Autoethnography: Process, product, possibility for critical social research. Thousand Oaks, CA: Sage.

Jones, S. H., Adams, T., \& Ellis, C. (Eds.). (2016). Handbook of autoethnography. New York, NY: Routledge.

Madison, D. S. (2011). Critical autoethnography: Method, ethics, and performance (2nd ed.). Thousand Oaks, CA: Sage.

Reed-Danahay, D. (Ed.). (1997). Auto/ethnography: Rewriting the self and the social. Oxford, UK: Berg.

Richardson, L. (1992). The consequences of poetic representation: Writing the other, rewriting the self. In C. Ellis \& M. Flaherty (Eds.), Investigating subjectivity: Research on lived experience (pp. 125-140). London, UK: Sage.

Spry, T. (2016). Autoethnography and the other: Unsettling power through utopian performatives. New York, NY: Routledge. 


\section{Author Contact}

Sherry Marx: Sherry.marx@usu.edu

School of Teacher Education and Leadership, Utah State University, 2805 Old Main Hill, Logan, UT 84322-2805, USA

Julie L. Pennington: juliep@unr.edu

College of Education/MS 288, University of Nevada, Reno, Reno, NV 89557, USA

Heewon Chang: hchang@eastern.edu

College of Business and Leadership, Eastern University, 1300 Eagle Road, St. Davids, PA 19087, USA 